\title{
Financial Integration, Banking Supervision and Sustainability of the Western Balkan Countries
}

\author{
Submitted 13/11/19, $1^{\text {st }}$ revision 20/12/20, $2^{\text {nd }}$ revision 06/01/20, accepted 28/01/20
}

\author{
Sh. Çitaku ${ }^{1}$, G. Asllani ${ }^{2}$, G. Luboteni ${ }^{3}$, S. Grima ${ }^{4}$
}

\begin{abstract}
:
Purpose: This paper examines the need of financial integration of Western Balkan countries as the main indicator of the region's economic growth.

Design/Methodology/Approach: We provide an overview in order to explain what the financial system in the region is. Primarily we concentrate in the banking sector and the nonperforming loans in the region. They require attention and standardization of regulatory classification. By establishing a regional platform it would be of additional value and would help overcome the limited visibility in some of the countries.

Findings: Currently the challenges for financial stability in the Western Balkan area comprise non-performing loans, low capital adequacy and moderate growth of credit in the economy. The banking sector is reducing the debt due to required financial stability measures of the European banking authorities. As these countries integrate their financial institutions and markets into the European financial system, on the path towards harmonization of national and European legislation, cooperation between financial entities in the Western Balkans becomes very important. The Western Balkan countries are in a different stage of development of banking sustainability and supervision and because of that there is a need for more integration with the European Banks and the respective regulators to ensure an adequate banking regime.

Practical Implications: The article highlights the fact that Western Balkan countries need to intensify their reforms to build banking sustainability in order to meet the criteria for EU membership.

Originality/Value: With this article we show that the Western Balkan countries in their integration processes must first align their local and European legislation and requirements.
\end{abstract}

Keywords: Integration, sustainability, finance, banking, nonperforming loans, supervision.

JEL Codes: D41, F12.

Paper type: Research article.

\footnotetext{
${ }^{1}$ University "Hasan Prishtina”, Pristine, Kosovo, E-mail: shkelqesa@gmail.com;

${ }^{2}$ Corresponding author, University "Haxhi Zeka", Peja, Kosovo,

E-mail: gani.asllani@unhz.eu

${ }^{3}$ Professor Doctor, University of Pristina”, Kosovo, E-mail: gazmend.luboteni@uni-pr.edu

${ }^{4}$ University of Malta, Department of Insurance, Faculty of Economics, Management and Accountancy, E-mail: simon.grima@um.edu.mt
} 


\section{Introduction}

As a consequence of a decade of ethnic conflicts, the Western Balkan countries have undergone political and economic reforms. Since 2003 when the Thessaloniki summit opened the prospect of EU accession, the Western Balkans has moved toward this reform (Council of the European Union, 2003). The financial integration of the Western Balkan countries into the European Union (EU) offers a lot of benefits but also exposes them to potential risks. This has been evident during the European financial crisis in 2008, wherein the high dependence on foreign funding of the Balkan countries reflected badly on economic activities. Western Balkan countries have social, cultural and economic similarities, but there are also some differences (Tmava at al., 2018). Nowadays, the Western Balkans financial system has a large presence of foreign-owned banks. Most of these banks come mainly from Austria, Italy, France and Greece.

The privatization of the banking sector in the Western Balkan countries has contributed to the strengthening of the financial and capital market and the diversification of the financial systems highlights an opportunity for improving financial stability. The continuous analysis of bank performance is essential for understanding the economic and finance prospects of a country and to determine the problem causing factors in order to avoid another crisis. To this date, the Western Balkans is still very vulnerable due to the effects of the Eurozone and the potential benefits from financial integration in the region are large. The banking system accounts for about $85 \%$ of the financial assets (World Bank, 2019) and as such plays a key role in the region's financial sustainability.

\section{Literature Review}

Frederic and Stanley (2011) noted that banking stability is mainly affected by financial institutions imbalance, decrease of asset prices, increase in interest rates and fiscal debts. Financial institutions imbalance relates to the liquidity problems and the costly liquidation of long-term assets (Goldstein and Pauzner, 2005; Malherbe, 2010). Banking literature frequently uses two measures to identify bank:

balance sheet problems that could cause financial instability:

$>$ non-performing loans (NPL) as a percentage of total assets;

$>$ bank lending as percentage of GPD.

If the bank lending expands quickly in a short period of time, this may lead to a high proportion of non-performing loans (Sachs et al., 1996; Rupeika-Apoga et al., 2018a; 2018b; Soloviova et al., 2018; Thalassinos et al., 2015).

NPLs are loans wherein the lender does not meet the contractual obligations within 90 days and the growth in NPLs reflects negatively on the bank's liquidity (Horwath et al., 2012). If preventing steps are not taken the NPLs negatively affect the 
stability of the banking industry. This is dependent on the generation of interest income through the lending capacities of the banks. In the event that the banks are not able to produce enough interest income, they would need to maintain reserves outstanding for any eventual loan problems. In fact, NPL can be treated as undesirable costs which can jeopardize a bank's performance (Hu at al., 2004). The lack of scale economy because of the limited size of the market and relatively low level of competition in financial and banking market has contributed to an increase in loan interest rates (Asllani, 2014). However, if because of the economic situation the demand for loans decreases then the NPL increases (Varesi, 2015).

The Capital adequacy ratio is the financial indicator used by banks to monitor performance, to show that depositors are protected and to promote the stability and efficiency of the financial systems (Basel Committee on Banking Supervision, 2015). Therefore, understanding the roles that banks have in the modern economy and their significance is fundamental for theoretical finance. Cross-country comparisons, individual country studies reveal a link among the banking systems, economic growth and sustainable development (Allen and Carletti, 2010).

Although, credit growth is considered to be a good indicator of banking stability, many relate it to increasing the possibility of a financial crises (Jakubik and Minescu, 2015). The indicators of bank credit enables us to forecast future economic conditions, where an immediate growth of credit supply could result in a financial crises followed by a recession in economic activities (Awdeh, 2017).

For the Western Balkan countries, the European Banking Union is a very important step towards further integration and coordination between local and host authorities (Stehrer and Holzner, 2018). Despite the current difficulties, the EU's political and economic integration agenda remains committed to this goal. Regional cooperation and communication become an indispensable objective of the Western Balkans integration process, at least for the banking and financial market reform.

\section{Methodology and Data}

Our analysis is focused on six counties in the Western Balkans, specifically Albania, Bosnia and Herzegovina, North Macedonia, Montenegro, Kosovo and Serbia. The data is collected from secondary sources such as scientific literature, World Bank reports, National Banks, Eurostat data, CEIC data, International Monetary Fund (IMF), financial statements and annual reports of countries.

\section{Financial System and Banking Sustainability}

The positive development in cross-border co-ordination and cooperation in the field of banking was the signing of a Memorandum between the European Banking Authority and the supervisory authorities of the banking system in the six Western Balkan countries. Albania, Montenegro, Serbia, Bosnia and Herzegovina and North 
Macedonia signed the memorandum in 2015 (European Commission/European Financial Stability and Integration, 2015), while Kosovo signed it in 2017. This nonbinding agreement created a framework of cooperation and exchange of information to strengthen banking regulation and supervision in the region. The commitment of Western Balkan countries to advance their reform will help to achieve balanced connectivity (Gould, 2018). The Western Balkan countries have agreed to provide the European Banking Authority with regular updates on banking developments and to bring their own standards and supervisory rules in line with those of the EU. However, the Western Balkan financial sectors are at different levels of development. Financial systems are bank-oriented, where banks have more than 90\% of financial institutions' assets in most countries, whereas investors (insurance companies, pension funds) and capital markets are at a lower level of development. According to the European Central Bank statistics, over $60 \%$ of banks in the Balkan region are composed of foreign capital or branches. Because of these circumstances the banking system in the Balkan region risk being affected by any international economic crises. However, the prospect of economic growth in the Western Balkans has of the late taken a positive trend, were in 2015 the real GDP growth was $2.2 \%$, increasing to $3.6 \%$ in 2018 (Table 1).

Table 1. Growth of GDP through 2015-2018

\begin{tabular}{|l|l|l|l|l|}
\hline Growth of GDP $(\%)$ & 2015 & 2016 & 2017 & 2018 \\
\hline Albania & 2.6 & 3.2 & 3.2 & 3.5 \\
\hline Bosnia and Herzegovina & 3.0 & 2.8 & 3.2 & 3.7 \\
\hline Kosovo & 4.1 & 3.6 & 3.9 & 4.2 \\
\hline North Macedonia & 3.8 & 2.4 & 2.8 & 3.3 \\
\hline Monte Negro & 3.4 & 2.1 & 3.3 & 3.0 \\
\hline Serbia & 0.8 & 2.8 & 3.0 & 3.5 \\
\hline Western Balkan & 2.2 & 2.8 & 3.2 & 3.8 \\
\hline
\end{tabular}

Source: Calculations are based on data extracted from Eurostat updated on March 2019 and World Bank Report http://data.worldbank.org/indicator/.

According to the World Bank analysis, the regional growth in 2019 will reach a peek as it grows slowly in Albania, Montenegro, and Serbia, but then gradually will recover in 2020 and is expected to grow faster (Table 2).

Table 2. The Growth trajectory through 2018-2020

\begin{tabular}{|l|l|l|l|}
\hline Growth of GDP $(\%)$ & 2018 & 2019 & 2020 \\
\hline Albania & 4.2 & 3.8 & 3.6 \\
\hline Bosnia and Herzegovina & 3.0 & 3.4 & 3.9 \\
\hline Kosovo & 4.2 & 4.4 & 4.5 \\
\hline North Macedonia & 2.7 & 2.9 & 3.2 \\
\hline Monte Negro & 4.4 & 2.9 & 2.4 \\
\hline Serbia & 4.2 & 3.5 & 4.0 \\
\hline Western Balkan & 3.8 & 3.5 & 3.8 \\
\hline
\end{tabular}

Source: Calculations are based on data extracted from Eurostat updated and World Bank Report http://data.worldbank.org/indicator/. 
Currently, the key challenges for financial stability in the Western Balkans are NPLs, lack of capital adequacy and slow growth of the economy.

Table 3. Nonperforming loans in Western Balkan Countries

\begin{tabular}{|l|l|l|l|l|l|}
\hline Growth of GDP (\%) & 2014 & 2015 & 2016 & 2017 & 2018 \\
\hline Albania & 22.4 & 18.2 & 18.3 & 13.4 & 11.3 \\
\hline Bosnia and Herzegovina & 14.0 & 13.7 & 11.8 & 10 & 9.4 \\
\hline Kosovo & 8.5 & 6.2 & 4.9 & 3.1 & 2.7 \\
\hline North Macedonia & 16.8 & 13.4 & 11.1 & 8.0 & 6.1 \\
\hline Monte Negro & 10.8 & 10.3 & 6.3 & 6.1 & 5.1 \\
\hline Serbia & 21.5 & 21.6 & 17.0 & 9.8 & 5.7 \\
\hline Average & 15.6 & 13.9 & 11.56 & 8.36 & 6.38 \\
\hline
\end{tabular}

Source: Data's are extracted from Eurostat updated on March 2019 and World Bank World Bank Report Nr. 15, 2019.

Overall, the NPLs are more prominent in a small number of domestic banks. More commitment is required to reduce them since high stocks of NLPs deters credit growth. According to the IMF, Albania and Serbia have the highest level of NPLs. For this reason, these two countries drafted a strategy covering the banking supervision part and a number of other aspects. Between the periods 2015 to 2016, the write-offs amounted to about $6 \%$ of total loans in Albania and more than $3 \%$ in Serbia. However, the banking system in Albania is well capitalized and liquid, but the credit in the private sector continues to cause problems. The main reason for this is considered to be the drop in foreign currency credit and that the credit in local currency was mostly taken up by households (World Bank, 2019). In September 2017, Albania marked the lowest level of NPLs which stood at $13.4 \%$ of the total dropping to $11.3 \%$ of the total as at December 2018.

In Kosovo, during the same period, the banking system had a growth of $10.8 \%$ in private credit, while the deposits grew by $6.4 \%$. The level of NPLs in Kosovo at 2017 was $3.1 \%$, down to $2.7 \%$ in 2018. In Bosnia and Herzegovina, the banking system is also liquid and well capitalized, although declining, but the capital adequacy is stable at $18.1 \%$ as at 2018 and the level of NPLs during 2017 was $10 \%$. In Montenegro the credit to the private sector grew by $10.2 \%$ in 2018 , and deposits grew by $7.6 \%$ during the same period. The level of NPLs in 2017 was $6.1 \%$ and $5.1 \%$ in 2018. In 2018 in North Macedonia credit growth was at 7.5\%, deposits growth 5.5\%. The level of NPLs in 2017 was $8.6 \%$ and $6.1 \%$ in 2018. The banking system in Serbia is identified with a moderate performance of banks. Deposits grew at $9.2 \%$ with domestic growth credit at 5.7\%. The level of NPLs in 2017 was $9.8 \%$ and $5.7 \%$ in 2018 (Table 3).

Overall, as one can note, the banking system in Western Balkan Countries is quite liquid, mainly due to the efforts to reduce NPLs and all have a capital adequacy ratio above the minimum of $12 \%$ recommended by the Bank of International Settlements (BIS) in Basel III. In fact, in 2018 the capital adequacy ratio in Kosovo was 17.0\%; 
in Albania 18.8\%; North Montenegro 16.5\%; Serbia 23.2\%; North Macedonia $16.5 \%$ and Bosnia and Herzegovina 18.1\% (World Bank, Western Balkans regular economic report, 2018). The regional average for growth in credit between July 2017 and 2018 was $8.5 \%$ compared to the December 2017. The average growth of deposits where $6.6 \%$ (Table 4). Table 5 presents nonperforming loans in EU countries under 3 million population, Table 6 deposits and credit in the same countries and Table 7 nonperforming loans for countries having presence in the Balkans.

Table 4. Domestic credit growth, capital adequacy ratio and reserve requested ratio $(2017 / 2018)$

\begin{tabular}{|l|l|l|l|}
\hline Country & Deposits & Domestic credit growth & Capital adequacy ratio \\
\hline Kosovo & 6.4 & 11.8 & 17.0 \\
\hline Montenegro & 7.6 & 10.2 & 16.0 \\
\hline Serbia & 9.2 & 5.7 & 23.2 \\
\hline North Macedonia & 5.5 & 7.8 & 16.5 \\
\hline Bosnia and Herzegovina & 9.9 & 5.5 & 18.1 \\
\hline Albania & 1 & 10.1 & 18.8 \\
\hline Average & 6.6 & 8.5 & 18.23 \\
\hline
\end{tabular}

Source: EU Candidate Countries'\& Potential Candidates 'Economic Quarterly (CCEQ). 2019. Technical paper 032 | April 2019. CEIC Data, 2019. https://www.ceicdata.com.

Table 5. Nonperforming loans in EU under 3 million population

\begin{tabular}{|l|l|l|l|l|l|}
\hline Growth of GDP $(\%)$ & 2014 & 2015 & 2016 & 2017 & 2018 \\
\hline Slovenia & 11.73 & 9.96 & 5.07 & 3.2 & 3 \\
\hline Malta & 3.90 & 4.68 & 4.13 & 3.05 & 3.1 \\
\hline Luxemburg & 0.2 & 0.2 & 0.9 & 0.7 & 0.6 \\
\hline Latvia & 4.59 & 4.64 & 3.6 & 3.5 & 3.4 \\
\hline Lithuania & 7.19 & 4.95 & 3.66 & 3.18 & 2.2 \\
\hline Estonia & 1.39 & 0.98 & 0.87 & 0.7 & 0.4 \\
\hline Cyprus & 44.9 & 47.7 & 48.68 & 40.17 & 40.10 \\
\hline
\end{tabular}

Source: CEIC Data, 2019. https://www.ceicdata.com.

Table 6. Deposits, domestic credit growth and capital adequacy ratio (2017/2018) in EU under 3 million population

\begin{tabular}{|l|l|l|l|}
\hline Country & Total deposits & Domestic credit growth & Capital adequacy ratio \\
\hline Slovenia & 12.6 & 13.3 & 18.1 \\
\hline Malta & 6.6 & 6.2 & 21.8 \\
\hline Luxemburg & 7 & 6.7 & 23.7 \\
\hline Latvia & 8.5 & 5 & 22 \\
\hline Lithuania & 6.7 & 5.5 & 19.7 \\
\hline Estonia & 9 & 5.8 & 21 \\
\hline Cyprus & -2.0 & -15.0 & 12.4 \\
\hline
\end{tabular}

Source: Data's are extracted from the Reports of National Banks and CEIC database: https://www.ceicdata.com. 
Table 7. Nonperforming loans in EU countries that have banks in the Balkan Region

\begin{tabular}{|l|l|l|l|l|l|}
\hline Growth of GDP (\%) & 2014 & 2015 & 2016 & 2017 & 2018 \\
\hline Greek & 33.78 & 36.65 & 36.30 & 45.57 & 45.20 \\
\hline Austria & 3.47 & 3.3 & 2.69 & 2.36 & 2.3 \\
\hline Italy & 17.1 & 17 & 17.30 & 16.40 & 14.38 \\
\hline France & 4.16 & 3.98 & 3.64 & 3.08 & 3.10 \\
\hline Germany & 2.34 & 1.97 & 1.71 & 1.6 & 1.50 \\
\hline
\end{tabular}

Source: CEIC Data, 2019. https://www.ceicdata.com

\section{Non-EU Countries and Banking Supervision}

The European banking sector has experienced major and important changes in its regulatory environment since the global financial crisis of 2008-2009. The transpositions of Basel Standards recommendations into the EU Capital Requirements Directives limit the financing of large international banking groups, thus affecting the affiliates of Western Balkan countries. The uncertainties associated with these and other ongoing regulatory developments could lead large cross-border banking groups to take precautionary measures to reduce operations in Western Balkan countries. Changes include rules that apply coercive measures on capital and capital quality, financing profiles, debt and risk management practices. Therefore, between 2006 and 2017, both home and host countries tightened their regulations on international bank operations. Regulations have become more stringent on the controls and reporting on foreign lending and liquidity coverage, to ensure sustainable financing.

Although Western Balkan countries are not members of the EU, euro-zone banks have a systemically important presence in non-EU countries, particularly banks from Austria, Greece, Italy, France and Slovenia. They have brought in new and better banking technology and management practices, increasing efficiency. In terms of total bank assets, between $80 \%$ and $90 \%$ are controlled by foreign banks. Three foreign largest banks in Kosovo, North Macedonia and Albania hold 2/3rds of the total assets and $45 \%$ in Serbia, Montenegro and Bosnia and Herzegovina.

The Western Balkan countries banking systems will have to face common challenges in the context of "the Single Supervising mechanism", "the Single Resolution Mechanism", and potentially "the European Deposit Insurance Scheme". The Single Supervising Mechanism will ensure that central banks and regulatory authorities in the region fulfil their responsibilities with regard to oversight and the implementation of macro-prudential policies.

This process can be strengthened further if central banks in the region improve their co-operation and are able to identify common positions in communication with the European Central Bank (ECB). The opportunity to co-operate with a single supervisor will be key to move faster in the integration process and at the same time to create a more appropriate ground for financial institutions in the region. This 
initiative was carefully guided by the Vienna Initiative 2.0. The Vienna Initiative 2.0 gathered officials from South East Europe on $13^{\text {th }}$ January 2014 in Vienna to design a coordinated platform between non-EU states in the South East Europe, the new European supervisory authority and other legislative authorities. This initiative has played a key role in ensuring financial intermediation of the private banking system in economies of the Western Balkan countries are stalled.

The Vienna Initiative, as a multilateral agreement between the IMF, the European Bank for Development and Reconstruction and other banks operating in the region, ensures that governments should provide support to banks in securing deposits and liquidity. This agreement is designed to prevent the withdrawal of foreign banks from the region in the event of a crisis. In addition, working on the implementation of various regulatory standards related to macro-prudential instruments is a way of dealing with the identification and treatment of NPLs.

Not so long ago, some countries in the region were affected by the process of reducing the financial intermediation in the EU (i.e. the so-called de-risking). This was obvious during 2012, following the demands for capital increase by regulators, accompanied by the November 2015 stress tests required by the European Banking Authority and the respective steps taken by the national authorities. In terms of macro-prudential requirements, it is evident that the economies in the Western Balkan region rely heavily on banks' financing and there is a need to direct credit flow back to the economy. It is therefore necessary to establish a sustainable macroprudential policy, both in terms of instruments and the institutional approach, for a more efficient and timely prevention of systemic risk. This should be accompanied by measures to strengthen the framework for the management of a possible financial crises. As a result, a macro-prudential policy would not only avoid any conflict with monetary policy but should complement it.

\section{European Progress Report on Western Balkan Countries}

Legislation on banking supervision to strengthen corporate governance and the management of risk has been the aim of all Western Balkan countries. In fact, in December 2018, the Central Bank of Kosovo and the ECB signed a memorandum of understanding with the objective of facilitating bank supervision and cooperation and the exchange of information. There is a need to ensure that consumers are adequately protected from unfair banking practices (European Commission, 2019a). The idea is to ensure harmonisation of the regulatory framework with Basel recommendations and the respective EU Directives and standards, and although the Kosovo Central Bank imposes a minimum capital adequacy ratio of $12 \%$ on banks, their capitalisation level, which is considered quite stable is well above the required minimum ratio (European Commission, 2019a).

In Albania, the Bank of Albania (BoA) has in 2018 established a Resolution Fund managed by the Single Resolution Board to ensure harmonisation is achieved 
efficiently and a cooperation agreement has been signed with them. Guidelines and regulations on capital adequacy, licensing and activity, risk management, reporting by savings and loan associations, and transparency for banking and financial product services are in place. Moreover, the BoA is soon to introduce a liquidity risk management regulatory framework in line with Basel III and the EU Capital Adeqacy Directives (CAD). In the meantime, the NPL ratio continued to decrease from $13.4 \%$ in January 2018 to $11.3 \%$ in January 2019, mainly due to write-offs and some loan restructuring (European Commission, 2019b).

In Montenegro, regulations are as yet only partially aligned with the banking EU requirements. Work is being mainly carried out on the capital requirements, bank recovery and resolution. In May 2018, an amendment to the Law on voluntary financial restructuring of debts to financial institutions was carried out and an extension was given for another year to further facilitate the resolution of the NPLs. In June 2018, the macro-prudential policy framework, which provides for guidelines in the case of financial stability systemic risks in the country, were adopted by the Central Bank of Montenegro, extending further their supervisory (European Commission, 2019e).

Pending formal adoption in the law, the Financial Stability Committee designated the central bank of North Macedonia as the bank resolution authority. New rules, which in line with European Banking Authority's guidelines on good supervisory and corporate banking practices, managing risks and licencing banks were adopted. Moreover, a new management strategy on non-performing loans was adopted. However, there is a need for further definition of the institutional set-up, resolution tools and mechanisms and efforts to align 1) national law with EU requirements on prudential supervision in order to protect consumers and prevent unfair banking practices and 2) the Financial Collateral Directive with the Settlement Finality Directive, which is not yet complete (European Commission, 2019f).

The Financial stability in Serbia was preserved and the financial sector showed an improved performance with Liquidity, although declining, being on the high side. This was reinforced by the rising economic activity and the high profitability of commercial banks. Moreover, the capital adequacy is being maintained well above the minimum set by the national bank. Also, the implemented NPLs' resolution strategy supported a further reduction by December 2018, to $5.7 \%$ of total gross loans and a forthcoming envisaged strategy will focus to help limit the rise in new NPLs. In fact, authorities are focussed on addressing the legacy NPLs in the portfolio of the Deposit Insurance Agency (European Commission, 2019c).

In Bosnia and Herzegovina, the financial sector has remained stable, but the banking sector supervision is hampered by fragmented competences. In some banks, governance and risk management is limited, posing risks in the event of financial stress. The banking supervision of those state banks is limited. The banking sector's overall capital adequacy ratio has remained above $15 \%$ of riskweighted assets, 
which is well above the country's regulatory minimum of $12 \%$. Non-performing loans, which accounted for $9.4 \%$ of total loans at the end of 2018, are concentrated in domestically owned banks and are largely a legacy issue. However, in combination with a moderate profitability this relatively high interest rate spread points to the remaining inefficiencies in the sector (European Commission, 2019d).

\section{Conclusion}

Western Balkan countries have chosen integration into the European Union in order to have long-term economic sustainability and prosperity. The prospects of the financial system in the region is very dependent on external factors and progress on structural reforms as they can strengthen regional co-operation. As noted above, the financial system in the region are primarily bank based concentrated with a relatively average level of capital market activity. Establishing a regional platform would be additional value that would help overcome the limited visibility of individual countries. Therefore, a political and economic integration will help to ensure financial integration and hence stability.

It is therefore important for the Western Balkan countries to know in advance and to understand the institutional and functional developments of the financial system in the EU, and in particular the banking mechanisms. Considering the size of Western Balkan economic and financial sectors, there is still place for further consolidation and banking sector increase in efficiency. To ensure this the Western Balkan countries in their integration processes, which are at different stages, should strive to align their institutions, local legislation and requirements to those of the EU and ensure cooperation between the countries on financial systems and regulatory oversight.

\section{References:}

Allen, F., Carletti, E. 2010. An overview of the crisis: causes, consequences and solutions. International Review of Finance, Vol. 10, No. 1, 1-27.

Awdeh, A. 2017. The Determinants of Credit Growth in Lebanon. International Business Research, 10(2), 9-19.

Asllani, G. 2014. The interest rate of the commercial banks in Kosovo and competition. EuroEconomica, 2(33).

Basel Committee on Banking Supervision. 2015. International Convergence of Capital Measurement and Capital Standards: A revised framework. Basel, Switzerland: Bank for International Settlements.

Bank for International Settlements, https://www.bis.org

Council of the European Union. 2003. Thessaloniki European Council. Presidency Conclusions. Document 11638/03.

CEIC data. 2018. https://www.ceicdata.com

EU Candidate Countries' \& Potential Candidates. 2019. Economic Quarterly (CCEQ) 1st Quarter 2019. European Commission. https://ec.europa.eu/info.

European Commission/European Financial Stability and Integration. 2015. 
European Commission. 2018. A credible enlargement perspective for and enhanced EU engagement with the Western Balkans, Communication COM, available at https://ec.europa.eu/commission/sites/beta-political/files/communication-credibleenlargement-perspective-western-balkans_en.pdf.

European Commission. 2019a. Commission staff working document. Kosovo, 2019 Report.https://ec.europa.eu/neighbourhood-enlargement/sites/near/files/20190529kosovo-report.pdf. Page 58.

European Commission. 2019b. Commission staff working document. Albania, 2019 Report. https://ec.europa.eu/neighbourhood-enlargement/sites/near/files/20190529-albaniareport.pdf. Page 64.

European Commission. 2019c. Commission staff working document. Serbia, 2019 Report. https://ec.europa.eu/neighbourhood-enlargement/sites/near/files/20190529-serbiareport.pdf. Page 65 .

European Commission. 2019d. Commission staff working document. Analytical 2019 Report. https://ec.europa.eu/neighbourhood-enlargement/sites/near/files/20190529bosnia-and-herzegovina-analytical-report.pdf. Page 102.

European Commission. 2019e. Commission staff working document. Montenegro, 2019 Report. https://ec.europa.eu/neighbourhood-enlargement/sites/near/files/20190529montenegro-report.pdf. Page 64.

European Commission. 2019f. Commission staff working document. North Macedonia, 2019 Report. https://ec.europa.eu/neighbourhood-enlargement/sites/near/files/20190529north-macedonia-report.pdf. Page 65.

European Commission. 2003. Western Balkans Summit Thessaloniki. https://ec.europa.eu/commission/presscorner/detail/en/PRES_03_163

Evans, D., Holmes, P., Iacovone, L., Robinson, S. 2004. A Framework for Evaluating Regional Trade Agreements: Deep Integration and New Regionalism. University of Sussex.

European Banking Authority, https://eba.europa.eu. EBRD. 2012. Integration across borders. Transition Report.

Eurostat, 2019. https://ec.europa.eu/eurostat.

Frederic and Stanley. 2011. Study Guide for Financial Markets and Institutions.

Goldstein and Pauzner. 2005. Demand-Deposit Contracts and the Probability of Bank Runs. Journal of Finance, 60, 1293-1327.

Gould, D. 2018. Critical Connections: Promoting Economic Growth and Resilience in Europe, World Bank.

Horwath, R., Seidler, J., Weill, L. 2012. Bank Capital and Liquidity Creation. European Central Bank, Working Paper Series, No 1497.

Hu, J., Li, Y., Chiu, Y. 2004. Ownership and Nonperforming Loans: Evidence from Taiwan's Banks. The Developing Economies, 42(3), 405-420.

IMF Country Report No. 19/293.

Jolevska, E., Andovski, I. 2015. Non-preforming Loans in the Banking Systems of Serbia, Croatia and North Macedonia. Ekohomska, 61(1), 115-130.

Malherbe, M. 2010. Self-fulfilling liquidity dry-ups. Research Series.

Qazim, T., Avdullahi, A., Sadikaj, B. 2018. Loan portfolio and nonperforming loans in Western Balkan Countries. Journal of Finance and Banking Studies, 7(4), 10-17.

Rupeika-Apoga, R., Zaidi, H.S., Thalassinos, E.Y., Thalassinos, I.E. 2018a. Bank Stability: The Case of Nordic and Non-Nordic Banks in Latvia. International Journal of Economics and Business Administration, 6(2), 39-55.

Rupeika-Apoga, R., Saksonova, S. 2018b. SMEs' Alternative Financing: The Case of Latvia. 
European Research Studies Journal, 21(3), 43-52, DOI: 10.35808/ersj/1042.

Sachs, S., et al. 1996. Financial Crises in Emerging Markets: The lessons from 1995. Economic Activity Paper.

Solovjova, I., Rupeika-Apoga, R., Romanova, I. 2018. Competitiveness Enhancement of International Financial Centres. European Research Studies Journal, 21(1), 5-17, DOI: $10.35808 / \mathrm{ersj} / 925$.

Stehrer, R., Holzner, M. 2018. The Vienna Institute for International Economic Studies. Western Balkans EU Accession: Is the 2025 Target Date Realistic?

Thalassinos, I.E., Stamatopoulos, D.T. and Thalassinos, E.P. 2015. The European Sovereign Debt Crisis and the Role of Credit Swaps. Chapter book in The WSPC Handbook of Futures Markets (eds) W. T. Ziemba and A.G. Malliaris, in memory of Late Milton Miller (Nobel 1990) World Scientific Handbook in Financial Economic Series Vol. 5, Chapter 20, pp. 605-639, ISBN: 978-981-4566-91-9, (doi: 10.1142/9789814566926_0020).

Varesi, L. 2015. Western Balkans' Banking Sector Performance in Terms of Macroeconomic and Bank Specific Efficiency Determinants. Acta Universitat1s Danubius, 11(1), 5-21.

World Bank. 2019. Western Balkans regular economic report, No.15. 